\title{
THE SECURED TRANSACTIONS ARTICLE OF THE COMMERCIAL CODE
}

\author{
Grant GiLMore*
}

Article 9, Secured Transactions, of the Uniform Commercial Code ${ }^{1}$ covers a great deal of territory. To use a jargon which was fashionable not long ago, it proposes to integrate, under a single system of legal propositions and a single system of terminology, the entire range of transactions in which money debts are secured by personal property.

The organizing concept which underlies Article 9 is that security transactions should be differentiated with reference to the status of the person whose property secures the debt and the kind of property put up as collateral-thus: consumer goods; ${ }^{2}$ farm products; ${ }^{3}$ and property used in business enterprises, which is subdivided according to whether it is intended for use in the business (equipment) ${ }^{4}$ or for sale (inventory) ${ }^{\sigma}$ or represents the proceeds of the sale of inventory (accounts receivable, ${ }^{6}$ "chattel paper," etc.). Armed with this battery of definitions, the draftsmen have found themselves able to make necessary distinctions between the unlike elements of different security transactions and at the same time to formulate a single set of rules to cover the very large area of likeness common to all such transactions. The negative side of this key concept is the proposal to abandon-almost completely, so far as terminology is concerned, and to varying degrees so far as substantive law is concerned-the traditional differentiation of security transactions according to the form of the security agreement, such as chattel mortgage, conditional sale, trust receipt, and so on.

No other Article of the Code proposes so radical a departure from prior law. Most of the Code is merely restatement. Since it is in the nature of statutes to freeze case-law development, any codification means periodic recodification. Business behavior and practice change, apparently at an accelerating tempo; if commercial law had been left to the courts without benefit of statute, necessary changes to adjust the law to practice could have been made in the course of decision. Such a gradual

- A.B. 1931, Yale College; Ph.D. 1936, LL.B. 1942, Yale University. Associate Professor of Law, Yale Law School; Associate Reporter, Article 9, Uniform Commercial Code. The ideas expressed in this article are those of the author alone and should not be taken as representing the ideas of the reportorial staff of the Code, of the American Law Institute, or of the National Conference of Commissioners on Uniform State Laws. The drafting staff for Article 9 consisted of Professor Karl Llewellyn, Columbia University Law School, Chief Reporter for the Code; Miss Soia Mentschikoff of the New York bar, Associate Chief Reporter; Professor Allison Dunham, Columbia University Law School, Associate Reporter for Article 9; and myself.

${ }^{1}$ All references to sections of the Code will be, unless otherwise indicated, to the Spring, I950, draft.

2 Section 9-rog(r).

- Section 9-rog(3).

- Section 9-106.

${ }^{3}$ Section $9-\operatorname{Iog}(4)$.

${ }^{5}$ Section $9-\operatorname{rog}(5)$.

${ }^{7}$ Section 9-105(I) (c). 
adjustment was made impossible by the adoption of the Uniform Sales Act and the N. I. L. in the years following rgoo. Therefore the Code is necessary today, and no doubt another Code will replace this one in the year 2000 or thereabouts. Nonetheless in the recodification most of the old law stands. In the Code, Article 3 (Commercial Paper) and Article 7 (Bills of Lading and Warehouse Receipts) are designed only to bring the existing statutes up to date and to resolve incidental conflicts that have arisen in their construction. Article 5 (Letters of Credit) codifies what has been a case-law field, but without intent to do violence to an eminently satisfactory case-law development. Article 2 (Sales) generally restates its predecessor, albeit with a few controversial novelties, such as the abandonment of the concept of title or property in connection with the rights of parties to a sales contract and the introduction of special rules applying to merchants and contracts between merchants. ${ }^{8}$ Article 9, however, deliberately cuts loose from all anchorage in the past. ${ }^{9}$. It cuts across what have been regarded as separate fields of law, introduces a completely new terminology, incidentally repeals much old law, and in the process creates, and attempts to solve, new problems of its own. ${ }^{10}$

The first question to be asked is: Is there any excuse for such a proposal? Law differs both from belles lettres and from engineering. In the law a prose style of easy and elegant simplicity is desirable without being necessary; the law can do very nicely, and even achieve something resembling justice, with a crazy, twisted, illogical framework which, applied to bridge-building, would send the structure crashing into the river. Article 9 can be justified neither on the ground that it is elegantia juris in action nor on the ground that its system of propositions brings logical symmetry into a field where neither logic nor symmetry has yet been able to establish a beachhead.

Our present system of security law works, however badly. A draft statute, which casts its net so wide, should be suspiciously examined before being accepted. It will not be accepted unless the present system is working very badly indeed and unless there is general agreement that the proposed novelties will do a significantly better job.

\footnotetext{
${ }^{8}$ For an indication of the degree of controversy which these modest novelties have aroused see Williston, The Law of Sales in the Proposed Uniform Commercial Code, 63 HARv. L. REv. 561 (I950); Waite, The Proposed New Uniform Sales Act, $48 \mathrm{Mrch}$. L. Rev. 603 (1950). In their defense: Corbin, The Uniform Commercial Code-Sales; Should It Be Enacted?, 59 YALE L. J. 821 (1950).

"See Comment No. 3 to Section 9-105, referring to the terms "debtor" and "secured lender" used in Article 9: "It is necessary to have a set of terms to describe the parties to a security transaction, but the selection of the set of terms applicable to any one of the existing forms (for example, mortgagor and mortgagee) might carry to some extent the implication that the existing law referable to that form was to be used for the construction and interpretation of this Article. Since it is desired to avoid any such implication, a set of terms having no common-law or statutory roots has been chosen."

${ }^{10}$ Article 9 has been discussed in the following articles: Dunham, Inventory and Accounts Receivable Financing, 62 Harv. L. Rev. 588 (1949); Llewellyn, Problems of Codifying Secturity Lau, 13 Law \& Contemp. Prob. 687 (1948); Ireton, The Proposed Commercial Code: A New Deal in Chattel Security, 43 ILl. L. Rev. 794 (1949); Kripke, The "Secured Transactions" Provisions of the Uniform Commercial Code, 35 VA. L. Rev. 577 (1949); Kripke, Chattel Paper as a Negotiable Specialty tsnder the Uniform Commercial Code, 59 Yale L. J. 1209 (1950).
} 
The draftsmen of Article 9 have been fortunate in finding unanimity on one point: the present system works very badly.

Large-scale lending on the security of personal property is a relatively recent phenomenon which has been rapidly growing both in importance and complexity. This is true of big business and small. Its big business form has been typically the long-term corporate bond issue secured by the corporation's real and personal property alike: in that form, the presence of many small and unorganized investors, and repeated demonstrations that the strong must prey on the weak, have led to increasingly severe protective legislation, state and federal, regulating the issue of such securities. On this type of security transaction Article 9 will have small impact; nor can it be said that Article 9 promises any significant benefits in the long-term field.

It is in the provision of working capital for small and medium-sized businesses and in the distribution of durable goods to consumers that secured lending has sprung up in a wild and rank profusion of short-term security devices: chattel mortgage; conditional sale; bailment-lease; trust receipt; factor's lien, possessory and nonpossessory; assignment of accounts receivable; field-warehousing; plus a variety of futuristic forms just beginning to be experimented with. Some of these devices have long-established common law or statutory roots and have been, or are in the process of being, adapted as well as may be to use under circumstances far different from those which called them forth. Others are new inventions, thought up to get around restrictive rules which were derived from the original uses of the older devices and have been perpetuated by the nature of the judicial process. ${ }^{11}$

Short-term security devices have multiplied because lending agencies have progressively lowered the barriers which once made it impossible for the marginal borrower to get bank money. The greater credit risk is sought to be mitigated by always taking security. The new borrower, however, cannot offer the traditional types of collateral: real estate, industrial equipment, or securities to be left in pledge. The old devices have to be stretched, or new ones invented, to deal with the new collateral: consumer durables; raw materials, work in process and finished inventory; accounts receivable.

With each expansion of the lending business a discernible pattern is repeated. As the lending agencies go into the business of financing a new type of borrower on a new type of collateral, an old security device is adapted, or a new one invented, to cope with the peculiar problems which arise. This is done in the first instance by contract between the parties. Since the lender feels that he is engaging in a risky transaction with a disreputable borrower on the security of unfamiliar collateral, he drafts the contract overwhelmingly in his favor. If in time it turns out that the transaction was money in the bank, the borrower a solvent and respectable citizen, and the collateral, in the rare case of default, as good as gold, the old harsh clauses have, nevertheless, a way of staying in the contract, through inertia or in terrorem;

${ }^{11}$ For a review of the development of some of these security devices, and an exposition of the point of view which was later adopted in Article 9, see Gilmore and Axelrod, Chattel Security, 57 YALE L. J. 5I7, 76I (1947). 
no abuse is involved, the lenders correctly point out, since no lender-no reputable lender-ever-or hardly ever-takes advantage of them.

Eventually the courts-in the case of commercial borrowers, usually the bankruptcy courts-pass upon the validity of these private security agreements. Since the agreements, however unconscionable they may be in form, are a response to real economic needs, the judicial response, sometimes after initial periods of hesitation, sometimes with qualifications, has usually been favorable. The trust receipt is recognized as an "independent" security device. ${ }^{12}$ The addition of a clause providing for a deficiency judgment is approved in conditional sales. ${ }^{13}$ Field warehousing, properly conducted, is found to be a permissible type of pledge. ${ }^{14}$ Assignments of accounts receivable, are subjected to severe restrictions but nevertheless preserved from recapture as voidable preferences. ${ }^{15}$

The third stage in the life history of a security device, following the drafting of the agreement and judicial validation, is the adoption of statutes regulating the device-although recently, with the development of improved lobbying techniques, there has been a tendency to skip the first two stages and start with a statute..$^{10}$ The forces which lead to the codification are diverse. From the lender's point of view, a well-drawn statute has several advantages: for one thing it makes the device safe, judge-proof, so to say, as barns are made rat-proof; for another, if the same or a similar statute is widely adopted, standardized forms can be used on a national scale, which makes for a cheaper operation and avoids many pitfalls. Unsecured creditor interests generally support codification under the battle slogan: Down with Secret Liens-since only by statute can the new or revamped common law device be subjected to filing or recording requirements. In the consumer field alone has the codification had reform overtones: here there have been two waves of protective legislation, the first around $\mathrm{rg} 20$ in the form of the Uniform Conditional Sales Act and similar legislation, the second around 1940 in the form of Retail Instalment Selling Acts. The I920 wave did nothing to correct the abuses inherent in instalment selling; it remains to be seen what the r940 wave will accomplish.

Before 1920 the chattel security legislation of a commercial state might well consist of a chattel mortgage act, drafted seventy-five years earlier, complete in one section, and providing: "Any chattel mortgage, or instrument in the nature of a mortgage on personal property, shall be recorded as in this Act provided ..."

\footnotetext{
12 The early cases are collected in Frederick, The Trust Receipt as Security, 22 Coz. L. REv. 395,546 (1922).

${ }^{13}$ For this development see 2 Garrard Glen, Fraudulent Conveyances and Preferences c. XXX (Rev. ed. I940).

14 See Birnbaum, Form and Substance in Field Warehousing, 13 Law \& ConteMp. Prov. 579 (1948).

${ }^{16}$ The literature on accounts receivable financing during the past half-dozen years has been cnormous, not to say stupefying, and will not be collected here. The reference in the text is of course to Benedict v. Ratner, 268 U. S. 353 (1925). It seemed for a while following the handing down of Corn Exchange National Bank \& Trust Co. v. Klauder, 3 I 8 U. S. 434 (r943), that the end was at hand; that unhappy consummation was avoided by a concerted rush to the statute books, see discussion infra p. 32 .

${ }^{10}$ E.g., The Factor's Lien Acts. These are briefly discussed in Gilmore and Axelrod, stipra note II at 768 , where some of the statutory citations are collected.
} 
Today the same state has on its books:

r. The same chattel mortgage act, with supplementary sections added at various times to subvert the common law mortgage rules in particular types of transactions (e.g., automobiles, crop mortgages, future advances, etc.) $;^{17}$

2. The Uniform Conditional Sales Act or a variant (passed between I920 and 1930);

3. A Motor Vehicle Title Registration Act (passed between 1920 and I940);

4. The Uniform Trust Receipts Act (passed between 1935 and r945);

5. A Retail Instalment Selling Act, administrative agency type or simple disclosure type (passed between 1940 and 1950);

6. An Act to Regulate Sales Finance Companies (passed between 1940 and 1950);

7. A Factor's Lien Act (passed between I940 and I950);

8. An Assignment of Accounts Receivable Act, filing or non-filing variety (passed between 1943 and 1950).

During the next ten years the same state, if it does not adopt Article 9, can expect to add at least the following new legislation:

I. A comprehensive stream-lined chattel mortgage act, repealing the old one; ${ }^{\mathbf{1 8}}$

2. A field warehousing act; ${ }^{19}$

3. A chattel lease act; ${ }^{20}$

4. A new motor vehicle code (since none of the present title registration acts is satisfactory) ;1 $^{21}$

5. Various amendments to the statutes already on the books, particularly the Retail Instalment Selling Act and Accounts Receivable Act. ${ }^{22}$

17 See, for example, N. Y. LIEN LAw. The basic section is $\$ 230$, which, according to McKinney, has been amended in I9II, I9I6, I92I, and 1937. To $\$ 230$ have been added $\$ 230-a$ (Chattel Mortgages on Stocks of Merchandise) (192I); $\$ 230-b$ (Chattel Mortgages on Agricultural Crops to secure purchase price of or moneys borrowed for seeds, fertilizers, feed, and other materials) (I94I); \$230-c (Chattel Mortgages by motor vehicle dealers; mortgage statement in lieu of filing mortgages; buyers in ordinary course of trade) (194r).

${ }^{18}$ Some states have already undertaken this chore. See e.g., Pennsylvania Chattel Mortgage Act of I945, 21 P S $\$ 940.1-940.16$.

${ }^{10}$ So far as I know, no state has yet passed a statute regulating field warehousing. The suggestion that, apart from Article 9, there will be such statutes is merely prediction, but $I$ will offer attractive odds to anyone who wants to bet the other way.

${ }^{20}$ "Chattel lease" or "chattel trust" is not, or is not yet, a term of art. The device I mean to refer to differs from the familiar bailment-lease in that the chattel lease contains no provision for transfer of title to the lessee at the end of the lease period. Yet it is unquestionably a security device and is not a "true lease"-such as the IBM lease arrangement. In the chattel lease the lease period is calculated with reference to the expected useful life of the chattel; at the end of the period, it is assumed, the chattel will be scrapped. It has made its appearance in airplane, and in motor vehicle equipment financing. The chattel lease is thought not to be covered by any existing statute. I know of no case which has yet passed on its validity or "independence."

${ }^{21}$ On the degrees of unsatisfactoriness see Leary, Horse and Buggy Lien Law and Migratory Automobiles, 96 U. of PA. L. Rev. 455 (1948). The Code does not contain a motor vehicle title registration act; one was projected, a tentative draft was prepared, but the attempt was abandoned when it was discovered that the Conference of Motor Vehicle Commissioners was preparing a draft statute of its own and would not agree to cooperate with the Code authorities. It is my understanding that the Motor Vehicle Commissioners have now abandoned their draft, but the information was received too late for the matter to be reintroduced into the Code.

${ }^{22}$ On the Retail Instalment Selling Acts, see infra pp. 44-46; for at least one point on which amendment of the accounts receivable statutes will be required, see infra pp. 32-33. 
If the legislation in prospect follows past patterns, the following predictions are safe: the new acts and amendments will be drafted by various hands, occasionally in the public interest; only a few will bear the imprimatur of the National Conference of Commissioners on Uniform State Laws, the others will adorn a basic core of substance with a whimsical variety of form; they will use conflicting, irreconcilable and idiosyncratic sets of definitions; each act which provides for public filing will set up a new and independent set of books and at least one hitherto undreamed of system of filing will be invented $;^{23}$ none of the new legislation, with the possible exception of the revision of the Retail Instalment Selling Act, will attract the slightest public interest, and the only voices heard at the legislative hearings will be those of finance company and bank counsel, together with an occasional announcement by a man from the National Association of Credit Men that he represents unsecured creditors and is satisfied with the proposed statute if it requires filing.

All of this-past, present, and future-is appalling. The direct cost-the time and expense involved in drafting the statutes and lobbying them through legislatures-is bad enough. But what is really serious is the progressive confusion which results from the yearly addition of still another eccentric piece of security legislation. The new acts overlap the old ones-as the Factor's Lien Acts overlap the Trust Receipts Act. Overlap in this field can mean catastrophe: an accepted judicial technique for voiding security transactions is to discover that a particular arrangement, although labeled by the parties with the name of one security device, was in truth another. As new filing systems are set up, the credit information which the public files are meant to supply becomes more and more difficult and expensive to find. A single state today will have a state filing system for one security device; county systems for the others; one statute will provide for filing at the mortgagor's residence; another for filing conditional sales where the collateral is located. An adequate credit check on any business enterprise requires investigating records in half-a-dozen different places. Credit information is useless unless it is kept up to date. The national and regional credit information agencies, which do the credit job for businessmen today, do not and cannot maintain facilities for keeping their credit ratings up to date under present filing systems. The multiplication of filing statutes is in itself self-defeating.

The passing of non-uniform statutes regulating particular kinds of lending can lead to unexpected tangles. By way of illustration, recent statutes in the accounts receivable field have created a problem which can be more easily stated than solved. More than thirty states have passed such statutes in the past seven years. About half of them are of the "validation" type: that is, assignments are validated when made without filing or any other formality. ${ }^{24}$ Three are "book-marking" statutes: an assignment is valid provided that the assignor's books of accounts are stamped

${ }^{28}$ As for example the proposal, debated and rejected in connection with the 1950 amendment to $\$ 60$ (a) of the Bankruptcy Act, to establish a national filing system for accounts receivable, using the Federal District Courts as filing places. I do not mean to characterize this proposal as silly; on the contrary it seemed to me to have a great deal of sense to it.

${ }^{26}$ See e.g., Cons. GEN. STAT. \$\$6718-6726 (Rev. 1949). 
with a record of the assignment. ${ }^{25}$ The balance are filing statutes. In a filing statute one essential provision is: what accounts are within the filing district? There are half a dozen criteria to choose from $:^{26}$ the account may be regarded as located at the place where the contract out of which it arose was executed; at the place where the goods were delivered or the services performed; at the place where it is payable; at the debtor's residence; at the seller's place of business; at the assignee's place of business. There has been no uniformity in drafting; one statute chooses one criterion, one another, some list them all. ${ }^{27}$ Some scrap all common law criteria and provide for filing only if the assignor's chief place of business is within the state. ${ }^{28}$ Assume that a mail-order house doing a national business assigns its accounts. Where should the assignee file to be assured of protection in case of the assignor's bankruptcy? Reflect, before answering, that there are more than 14,000 counties in the United States. So long as all states validated assignments without filing-which was the case until 1943 - there was no problem. ${ }^{29}$ Now there is a problem but no one knows the answer.

The foregoing review is designed to make the point that our system of security law is badly in need of an overhauling. I have yet to meet anyone who operates in, or is familiar with, the field who denies this.

Furthermore, I think it is fair to say that there has been general agreement that the basic structure of Article 9 is sound. Indeed no other way out of the swamp has been suggested.

That basic structure has remained constant for the three years during which Article 9 has been in process of drafting. Only one notable structural change has been found advisable: the initial division of the Article into autonomous Parts, each Part dealing with a separate type of financing, proved to be unnecessary. ${ }^{30}$ As the

\footnotetext{
${ }^{25}$ Georgia, GA. CODE ANn. \$85-I803 (Temp. Supp. I949); North Dakota, Rev. Code of I943 (Supp. 1949) \$9-1 rog; Pennsylvania, 69 P S $\$ 561-563$.

${ }^{20}$ I know of few things less satisfactory than the common law handling of the question of situs of choses in action. The following cases, among others, bear more or less vaguely on the point: Hanna v. Lichtenhein, 181 App. Div. 94, 169 N. Y. Supp. 589 (Ist Dep't I918); Wishnick v. Preserves \& Honey Inc., 153 Misc. 596, 275 N. Y. Supp. 420 (1934); In re Loeb Piano Co. Inc., 178 La. 920, 152 So. 565 (1934); Clark v. Connecticut Peat Co., 35 Conn. 303 (1868); Lewis v. Lawrence, 30 Minn. 244, I5 N. W. Ir3 (1883); Gordon v. Vallee, Ix9 F. 2d II8 (5th Cir. I94I), cert. denied, 3I4 U. S. 644 (I94I); Sanders v. Armour Fertilizer Works, 63 F. 2d 902 (5th Cir. 1933) aff'd, 292 U. S. 190 (1934); Bundy v. Commercial Credit Co., 200 N. C. 51 I, 157 S. E. 860 (193I). I am indebted to Homer Kripke, Esq., of the New York bar for the foregoing citations. See also Restatemenr, Conflict of Laws $\$ \$ 350,353,354$, 358,366 (1934).

${ }^{27}$ For a horrible example of the last-mentioned type, see the North Carolina statute, N. C. GEN. STATs. Art. I4, \$44-78(5) (Supp. I949): "An account shall be deemed located in this state: (a) if the transaction out of which the account arose occurred in this state, or if payment is to be made in this state, or (b) if the account has been transferred to this state so that the place of payment of the account is in this state, or (c) in all other cases where an account is deemed located in this state under general rules of law."

${ }^{28}$ E.g., Florida: FLs. Ststs. ANN. $\$ 524.01-.06$.

${ }^{20}$ So far as the validity of the assignee's security interest was concerned. There was of course conflicts of laws litigation, as in the cases cited sipra note 26 .

${ }^{30}$ The Parts originally contemplated were: Pledge, Inventory and Accounts Receivable Financing, Equipment Financing, Agricultural Financing, Consumer Goods Financing. Article ro of the Code
} 
work of drafting progressed, it became clear that the areas of similarity in various types of financing were even greater than had been at first supposed. As agreement on these progressively larger areas was reached, the need for retention of the autonomous Parts became less, and they were dropped. It then became possible to organize the Article as a single entity, with a considerable saving in wordage; where special rules are applicable to different financing situations, they are now stated section by section as appropriate, and the number of such special rules is much less than might be supposed. ${ }^{31}$ This bit of drafting history suggests, I believe, that Article 9 was soundly conceived: the initial and basic assumption that the superficial dissimilarities among different financing transactions concealed a large core of similarity proved to be workable in an even larger area than the draftsmen had anticipated.

Despite the persistence of the central idea, unchanged, Article 9 has undergone serious revision in its successive drafts and the end it not yet. Many of the changes have been merely verbal: drafting is a constant labor to simplify-the first accurate statement of a complex point, reached after much toil and sweat, is typically phrased in a gibberish understandable only to the draftsmen; the job of putting it into English without sacrificing accuracy is never-ending. Many other changes have been made in response to technical information supplied by financing agencies and have been designed to make the statutory text more accurately reflect operating methods. A good number of changes have been made in the course of long-continued debate over disputed matters of policy; some ideas which made sense to the drafting staff have been scrapped when it became apparent that their real or fancied novelty would stir up a degree of controversy that might jeopardize the enactment of the Article.

Despite agreement on the key propositions that present security law works very badly and will work even worse and that the approach adopted in Article 9 offers the only practicable solution, doubts have been, and continue to be, expressed as to the wisdom of enacting the Article in its present form or in any form that the sponsoring organizations will conceivably approve. Expressions of doubt come with equal vigor from what may, for shorthand purposes, be called the Right and the Left.

From the Left we hear that Article 9 is a sell-out to the vested interests at the expense of the public interest. It is pointed out that Article 9 with a liberal hand removes most of the restrictions and limitations on lender's operations which have grown up over a century at common law and under statute.

The catalogue of such liberalizing provisions is a long one. For example: the floating charge, or lien on a shifting stock of goods, which under chattel mortgage law was typically held to be absolutely void as a matter of public policy, ${ }^{32}$ is validated

(Bulk Transfers) originally appeared as a Part of the Article as did the proposed motor vehicle title registration act, which was later abandoned for the reason stated supra note 21. Scc the May 1949 Draft of the Code.

${ }^{31}$ The Comment to Section 9-I02 lists and indexes these special rules.

${ }^{32}$ See Gilmore and Axelrod, supra note II, at 533 et seq. 
without limitation..$^{33}$ A security interest is allowed to pass over and affix itself to proceeds arising on disposition of the collateral. ${ }^{34}$ Article 9 , furthermore, repeals, ${ }^{35}$ in the field of accounts receivable financing, the rules, suggested in Benedict v. Rat$n e r^{36}$ and hammered out in the famous line of subsequent cases, ${ }^{37}$ which require the assignee of the accounts to keep, day by day, an unrelenting watch over the assignor's affairs. The after-acquired property clause is allowed full operation, ${ }^{38}$ resulting in a full-fledged security interest rather than a ghostlike thing wearing the veil of "equitable mortgage"; and the interest is protected, in so far as a state statute can do so, from the paralyzing attack of antecedent debt-and thus voidable preferencein bankruptcy. Even the long-held theory that it is both a legal and a logical impossibility to make a valid present assignment of future accounts ${ }^{39}$ is quietly buried, the operation being treated as merely another instance of after-acquired property. ${ }^{40}$ Future advances are treated on the same footing with present advances, ${ }^{41}$ thus saving many arrangements which have heretofore fallen afoul of vaguely articulated but deeply rooted prejudices. ${ }^{42}$ Crop mortgages are allowed to run beyond the planting season. ${ }^{43}$ The formal requisites for a security agreement are reduced to an almost invisible minimum: ${ }^{44}$ gone are the affidavits of good faith which the chattel mortgage statutes have long required as a deterrent to fraud; gone the requirements of notarization, verification, or other solemnities of execution; gone, at least to the extent that a statutory declaration can control the courts, the need for exact and specific description of collateral. ${ }^{45}$ Most serious of all is the abandonment of the restrictions which have hemmed in the lender's freedom of action in dealing with the collateral after default: there is in Article 9 no requirement of sale at public auction following public notice; no requirement that repossessed collateral be held for a specified period before disposition or that the collateral be disposed of within a specified period

\footnotetext{
${ }^{33}$ The result is reached by reading Section 9-203 on after-acquired property together with Section 9-208 permitting use or disposition without accounting.

3t Section 9-306.

${ }^{35}$ Section 9-208.

${ }^{30} 268$ U. S. 353 (1925).

${ }^{37}$ In re Bernard \& Katz, 38 F. 2d 40 (2d Cir. I930); Lee v. State Bank and Trust Co., 54 F. 2d 518 (2d Cir. I93I); Goldstein v. Rusch, 56 F. 2d ro (2d Cir. I932).

${ }^{38}$ Section 9-203.

${ }^{30}$ Taylor v. Barton-Child Co., 228 Mass. 126, II7 N. E. 43 (I9I7).

${ }^{40}$ Section $9-203(x)$ and (2)(c).

${ }^{41}$ This is made explicit in Section 9-203(5), September 1950 Revision. The draftsmen had considered it implicit in earlier drafts of the section.

¿Although, outside Connecticut, a mortgage to secure future advances was not considered fraudulent and void as a matter of law, such an instrument was regarded with suspicion and explanations were required. The future advance arrangement was, to say the least, vulnerable. See I Garrard GleNi, Fraudulent Conveyances and Preferences $\$ \$ 372$, 372(a) (Rev. ed. I940).

${ }^{43}$ Section 9.203(3)(a). The Spring, 1950, Draft limits the permissible time in most cases to one year after execution of the security agreement. The September r950 Revision leaves the time blank, so that each state can follow local policy on this point. Although the one year or planting season limitation is typical, some states (see e.g. Calif., Crv. Code (I949) $\$ \$ 2974-2978$ ) are more liberal.

"Section 9-204. For most non-possessory security interests: "in writing . . . signed by the debtor ... containing a description of the collateral. ..."

"Section 9-207(I).
} 
after repossession; no requirement even that the collateral be repossessed, since it is provided that the lender may deal with and dispose of it on the debtor's premises. ${ }^{40}$ In place of all these protective devices, designed to block the real and present danger of fraud or overreaching, there is erected only the flimsiest of safeguards: the lender, in dealing with the collateral, must observe a standard called "commercial reasonableness," an undefined term of no known legal meaning. ${ }^{47}$

It is argued that this extraordinary liberality toward lending interests is unwise from more than one point of view. The debtor, who is from economic necessity in an inferior bargaining position, is stripped of the safeguards which have been built up for his protection. This will lead to harsher bargains dictated by a class never noted for its propensity to underreach where overreaching is not forbidden by law. And even if the reputable lending agencies police themselves, partly because of their size and partly because they are able to deal only with solvent debtors, the marginal debtor, who must perforce borrow where he can on whatever terms are offered, will be an expertly shorn lamb for whom the wind will not be tempered.

But, it is further argued, consequences even more serious than the increase of fraud, overreaching, and unconscionable conduct may be expected. The proposal is to make the taking of security easy, cheap, and certain. The old restrictions had the effect of protecting a necessitous borrower against himself by making it difficult, if not impossible, for him to encumber all his assets. The existence of a cushion of free assets made it possible for him to get unsecured credit, particularly from his trade suppliers. Whatever may have been the articulate reasons for the invalidation of the floating charge or the Benedict v. Ratner restrictions, such judicial rules had the salutary result of assuring a healthy flow of unsecured credit. If fixing a valid lien on all the assets of a business enterprise is made as easy as rolling off a log, the supply of unsecured credit will dry up. Trade creditors and others who today make unsecured advances will for their own protection have to sell for cash or take security. Either alternative is bad. The debtor will become increasingly dependent on his supplier of working capital; the power to make business decisions will more and more pass to the lenders. The general availability of security will lead to other unhappy results: the marginal borrower will find it easier to get working capital; many enterprises, which have no economic reason for existence, will live when they should die and be liquidated. The coddling of unhealthy enterprises will harm unsecured creditors, who will have no protection when the security holder decides to call his loan and close the books on a debtor. This type of lending and the encouragement of risky salvage operations will have an inflationary effect which can be exceedingly dangerous at certain phases of the business cycle.

Thus the criticism from the Left or public interest point of view. A rather different criticism is launched from the Right.

\footnotetext{
${ }^{4}$ Section 9-503.

17 Section 9-504(2). The same concept of "commercial reasonableness" appears in Article 2 (Sales), Section 2-706 (Seller's Resale), and in Article 7 (Warehouse Receipts, Bills of Lading etc.), Section $7-409$ (Enforcement of Warehouseman's or Carrier's Lien).
} 
We now hear that Article 9, apart from certain minor relaxations of out-dated common law rules, imposes extremely harsh restrictions on lenders. It is said that Article 9 betrays an earnest reformist zeal, reminiscent of the crusading moralism of the lush days of the New Deal, entirely out of place in a commercial codification.

The list of right-wing grievances is fully as long as the one prepared on the other side of the fence.

Most frequently and violently attacked as an example of misplaced reformist zeal is the section which in the case of a security interest in consumer goods requires that certain information be made available to the consumer-debtor at or before the time he enters into the security agreement. ${ }^{48}$ A breakdown of items constituting the total time price is provided for: the cash price, the time-price differential, the amount of any down payment, an estimate of the amount charged for insurance, must be stated as separate items. Penalties are provided for failure to comply: loss of the time-price differential when a complying form is inadvertently incorrectly filled out; loss of the differential plus loss of the security interest in other cases.

Some background is necessary for the reader to appreciate the nuances of the attack to which the foregoing provisions have been subjected. To date thirteen ${ }^{49}$ states have enacted so-called Retail Instalment Selling Acts, each of which contains "disclosure" provisions comparable to those outlined above. This consumer protective legislation had its inception some fifteen years ago. The earliest acts were bitterly opposed by the sales finance companies, who seem, however, now to have modified their legislative strategy: while not advocating passage of such legislation, they have abandoned the effort to block it completely and instead exert themselves to see that the legislation as passed is "reasonable." For whatever reasons, the acts passed since roughly I945 lack some or all of the more restrictive provisions of the earlier acts. Today the so-called "Model" Retail Instalment Selling Act has the indorsement, if not the active support, of the sales finance companies. ${ }^{50}$

To some extent the disclosure provisions of Article 9 have been attacked in toto as unnecessary and undesirable matter for a Commercial Code, destructive of the right of freedom of contract, and illustrative of a "paternalistic," even "socialistic," attitude which is said to underlie much of the Code and particularly Article 9. This root and branch opposition has not, however, typically been expressed by representatives of the sales finance companies. Their attitude, rather, has been one of willingness to accept reasonable disclosure requirements; the Article 9 provisions,

\footnotetext{
${ }^{48}$ Section 9-205. The September 1950 Revision adds the "at or before the time he enters into the security agreement" language.

- California, Connecticut, Indiana, Maine, Maryland, Massachusetts, Michigan, New Jersey, New York, Ohio, Pennsylvania, Utah, Wisconsin.

${ }^{50}$ Counsel for these companies are adept at looking through form to substance. Thus the Act may vary in detail from jurisdiction to jurisdiction and still be the Model Act, just as a popular tune may be served up in several different arrangements. For a version high on the finance companies' hit parade see the Connecticut Act, Conn. Gen. Stats. $\$ \$ 6698-6704$ (Rev. 1949). For an Act that is not the Model Act, see Maryland, Code Art. 83, \$116-140 (Cum. Supp. 1947).
} 
they say, resemble those found in some of the earlier acts, which have proved to be "unworkable."

Issue is joined principally on two points. One is the separate statement of the insurance charge. It is argued with great vigor that figuring the actual insurance charge is a matter of much complexity; the consumer contract is filled out by dealer's clerks on a busy sales-room floor; mistakes are inevitable. It is suggested that, as under the Model Act, the estimated insurance charge be lumped in with the finance or carrying charge. To comply with requirements of State Insurance Commissioners, the actual premium must sometime be figured out, but this can be better done by the finance company itself after assignment of the contract. ${ }^{50}$ When the actual premium has been determined, no attempt will be made to adjust mistakes. If the insurance charge was understated, the amount received on carrying charge will be decreased; if overstated, the carrying charge benefits pro tanto. This is merely a bookkeeping transaction. The consumer is not assessed for any deficiency; nor does he receive a rebate if the estimate was overgenerous. ! The dealers, of course, make the original estimate of the insurance premium from tables provided by the finance companies.

The second principal issue is that of appropriate penalties for failure to comply with the disclosure provisions. The Article 9 penalties are denounced as unduly harsh and resort is once again had to the Model Act, which reads as follows:

A wilful violation of any provision of this chapter by any person, firm, association or corporation shall bar recovery of any finance, delinquency or collection charge by the owner or holder of the retail instalment contract or any interest, delinquency or collection charge by the owner or holder of an instalment loan contract involved, provided such owner or holder approved of or had knowledge of such violation and after such approval or knowledge retained the benefits, proceeds, profits or advantages accruing from such violation or otherwise ratified such violation. ${ }^{51}$

Chances for any recovery for any violation are not bright under the section just quoted. 50

${ }^{\text {Eoa }}$ So far there is no quarrel. Article 9 permits the statement of the insurance charge as an approximate sum or estimate, subject to later verification. The controversy, which has generated enormous heat without producing any light, goes to the narrow point whether the estimate must be stated separatcly or may be lumped. The finance companies are very clear: They do not like the separate statement, they would rather lump it.

${ }_{51}$ The language quoted is from Conn. Gen. Stats. $\$ 6703$ (Rev. 1949). Cf. Martinand Code Art, 83 \$136, (Cum. Supp. x947): "Whenever an installment sale agreement does not contain the material required by Sections $1 \times 6$ and II7 of this subtitle or the seller fails to deliver a copy to the buyer, no seller or holder of such agreement shall collect or receive any finance, delinquency or collection charge from the buyer...." The proponents of the Model Act are agreed that some penalty provision is necessary, perhaps becausc of the experience in California where an Act without any penalty provision was passed. In Carter v.

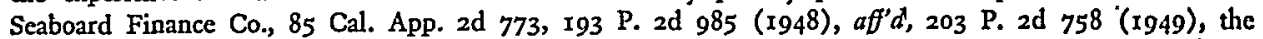
court held that the proper inference to be drawn from the omission of a penalty section was unenforceability of a non-complying contract.

52 Plaintiff to recover under the section quoted must prove ( $(1)$ wilful, (2) approval or knowledge, (3) after approval, retention of benefits, etc., accruing from violation, or other ratification. Presumably "otherwise ratified" is to be construed ejusdem generis with "benefits, profits, proceeds or advantages." It is hard to imagine a case where benefits etc. would accrue from the violation. 
The Article 9 treatment of waiver of defense or so-called cut-off clauses, whereby the debtor agrees not to assert defenses against any assignee of his contract, has been criticized. $^{53}$ Here again Article 9 singles out the consumer for special treatment: as to him such clauses are invalid. Indeed, in the consumer field, where the debt is evidenced by a negotiable note which comes into the hands of a holder in due course, Article 9 provides that a holder, even in due course, becomes subject to defenses if he seeks to enforce his security interest in the collateral. Outside the consumer field, the waiver is allowed to operate in favor of an assignee for value in good faith and without notice to the extent of cutting off defenses which would not be good against a holder in due course of a negotiable instrument. In this set of provisions, the treatment of the consumer's negotiable note has been attacked with particular violence: the provision, it has been said, will throw doubt on the validity of all negotiable paper; it will make it more difficult for the sales finance companies to obtain bank credit through pledge or rediscount of their consumer paper, since the banks will accept as security only paper which is fully negotiable; it is an unwarranted and doctrinaire attempt to correct fancied abuses which do not in fact exist. ${ }^{54}$ Quite apart from the consumer's negotiable note question, it is said that the invalidation of the contractual waiver in the consumer field and the limitations on its full effectiveness outside the consumer field cast upon the financing assignee risks which he should not be required to assume. Disputes between sellers and buyers, it is argued, should be settled directly between them and there is no valid consideration of public policy which forbids the assignee from acquiring by contract a position free from such disputes.

A problem not unrelated to waiver of defenses is that of the freedom of the seller and buyer-or assignor and account debtor, in financing terminology - to modify their original agreement without the assignee's consent. Article 9 provides that, ${ }^{55}$ apart from an effective waiver under the provisions just discussed; an assignee takes subject to all defenses arising from the contract and to all defenses, whether or not arising from the contract, which accrue before the account debtor is notified of the assignment. Furthermore, when an assignee leaves chattel paper in the assignor's hands for collection, the account debtor is authorized to pay the assignor even though he may have received notification of the assignment. And finally, when the subject matter of the assignment is money to become due under a contract for services not performed when the assignment is made, the rule is that despite notification to the account debtor of the assignment, any good faith modifications in or substitutions for the original contract are effective against the assignee, who, however, acquires corresponding rights under the modified or substituted contract. These provisions, it is said, particularly the last mentioned rule, once again cast upon the assignee a

\footnotetext{
E3 Section 9-209.

${ }^{54}$ See Kripke, Chattel Paper as a Negotiable Specialty under the Uniform Commercial Code, 59 YaLE L. J. 1209 , 1214 et seq. (1950).

${ }^{\mathrm{E}}$ Section 9-317.
} 
much greater business risk than he should be made to assume. The rule, furthermore, does violence to accepted theories of contract law..$^{66}$

A recurrent theme in these objections is that Article $g$ casts upon the lender business risks from which he has hitherto been free. Another example of this is the treatment of the problem arising when collateral subject to a security interest in State $A$ is removed to State $B{ }^{57}$ Present law, typified by the Uniform Conditional Sales Act, ${ }^{58}$ is that the State $A$ lien continues good in State $B$, refiling in State $B$ being required only after the lender actually learns of the removal and the present location of the goods. Article 9 adopts a radically different approach and requires refiling in State $B$ within four months after removal, without regard to the lender's knowledge of the removal. On the lender's behalf it is pointed out that he cannot possibly keep a day by day watch over the location of his collateral and that there will be many cases where the four months' period will have run without his having any reason to suspect removal. Thus in a situation which the lender cannot control, and which results from the debtor's fraudulent activity in which the lender is in no way at fault, the lender is faced with possible subordination to the debtor's State $B$ creditors. This, it is argued, is unjust.

The filing provisions of Article 9 have been attacked as being unduly broad in scope. Article 9 provides for filing of assignments of accounts receivable. ${ }^{50}$ This has of course been a matter of hot controversy for several years. The advocates of non-filing argue that no harm is done to other creditors by a failure to file; that businessmen who assign their accounts do not want the assignment to become a matter of public record; that the requirement of filing stifles a legitimate business operation. They point out further that non-filing is the majority rule, since of the thirty odd accounts receivable statutes only about half require filing, and of the states which have not passed statutes none requires filing. Another filing provision which has aroused controversy requires filing of so-called field warehousing or field storage arrangements. ${ }^{60}$ Field warehousing is a device, originated some fifty years ago, presumably to circumvent the chattel mortgage restrictions against a lien on a shifting stock. ${ }^{61}$ Field warehousing involves the lease at a nominal rental of a part of the debtor's premises to a field warehouseman. The warehouseman posts signs on the leased premises, issues non-negotiable warehouse receipts covering the goods in the warehouse, and installs its own custodian, who alone has access to the premises and who keeps detailed records of deposits in and withdrawals from the warehouse.

${ }^{80}$ It does violence certainly to the rule set out in RestateMEeNt, Contracts 5167 (1932). Whether $\$ 167$ accurately states the cases is another question.

${ }^{87}$ Section 9 -I03(2).

${ }^{88}$ Section 14.

${ }^{59}$ Section 9-303. Exempted from filing are assignments which are not "for the purpose of financing" -as assignments for collection only-or which do not transfer to the assignee a "significant part" of the assignor's outstanding accounts.

${ }^{\circ 0}$ Section 9-305(2).

ox On the mechanics of field warehousing, see Birnbaum, supra note 14. The standard articles reviewing the cases are Friedman, Field Warehousing, 42 Cor. L. Rev. 991 (1942); Kane, The Theory of Field Warehousing, 12 WASH. L. REV. AND StaTE BAR J. 20 (1937). 
Field warehousing arrangements, properly conducted, are universally recognized as valid by the courts. Since the form of the device is that of pledge, no filing is required. Article 9, which validates the lien on shifting stock, requires filing for perfection of a field warehousing arrangement on the theory that the pledge is fictional and that this is merely a sub-species of inventory financing, appropriately subjected to filing. The filing provision has been violently attacked as prejudicial to the field warehousing industry and as placing it at a competitive disadvantage with public warehouses, since there is no provision in Article 9 which requires filing to perfect a pledge of an ordinary warehouse receipt. ${ }^{62}$

Finally, in connection with the default provisions, the imposition on the lender of a duty to dispose of collateral in a "commercially reasonable" manner ${ }^{63}$ is attacked. This provision, it will be remembered, has also been attacked as altogether too flimsy a protection, in view of the removal of common law safeguards, for the interests of the debtor and his other creditors. The attack from the lender's point of view is that altogether too high a standard of duty is imposed and that the lender is exposed, despite the presence of language designed to clarify certain types of permissible behavior, ${ }^{64}$ to an uncertain liability of indefinite scope.

In the foregoing review of the criticisms which have been directed against Article 9, comment on their soundness has been in large part withheld. There is no reason to suggest that the two sets of criticisms cancel each other out. Nevertheless their co-existence gives reason to believe that Article 9 is neither a sell-out to the vested interests nor yet an all-out reformist effort. It could of course still be true that the particular relaxations of old rules as well as the particular instances of tightening up old rules were in all cases unwise or improvident. The author of this paper, as a draftsman, is naturally inclined to believe that Article 9 is a reasonable compromise among conflicting interests, that its enactment will work more good than harm, and that the provisions which have been drawn in question are fair solutions to complex problems.

\footnotetext{
${ }^{83}$ Since the question of field warehousing will not be specifically discussed in the balance of this paper, the point will be made here that the provisions of Article 9 which do adversely affect field warehousing are those which validate the floating charge. The filing provision is a pin-prick at most. But the floating charge battle has already been fought and (from the field warehousing point of view) lost, quite apart from Article 9, under the Factor's Lien Acts, referred to stpra note 16 , and see discussion infra p. 42. With the general validation of the floating charge, the magic has gone from field warehousing. In so far as the industry performs an economic function-stock control, detection and prevention of fraud etc.-it will prosper; in so far as it serves a purely metaphysical one, it will not. Far from being harmed by the filing provision, the industry should benefit from it. Under filing, the lender can be sure that he has a valid security interest; today he can be sure of it only when a court finds, as a question of fact, on testimony after the event, that the field warehouse was "properly conducted"i.e., conspicuous signs, independent custodian, denial of access to the pledgor, etc. Many of the field warehousing arrangements that have been litigated have not withstood the factual inquiry.

o3 Scction 9-504.

o4 Section $9-507(2)$. Sales in a recognized market, or at a price current in such a market, or in conformity with reasonable commercial practices among dealers are all stated to be "commercially reasonable," as is any plan of realization for which the foreclosing lender obtains advance approval in a judicial proceeding or from a bona fide creditors' committee.
} 
It is my own impression that what have been described as the criticisms from the Left are, if valid, more serious and disturbing than those from the Right. I do not believe that they are valid.

The restrictive rules, common law and statutory, abandoned or abolished by Article 9, have long since ceased to serve any useful purpose. Their vestigial survival works only to trap the unwary and the ill-informed and to penalize legitimate financing operations.

Take for example the rule invalidating mortgages on a shifting stock. It is a long time since this rule has had any real effect in preventing inventory financingwhich is what it was supposed to do. The development of field warehousing effected the first considerable breach in the fortress wall. Field warehousing was used typically to cover manufacturing inventory, and its rather cumbersome techniques were not easily adaptable to the case of a dealer's stock in trade. The extension of the import trust receipt to the domestic distribution of consumer's durable goods took care of the dealer's situation. ${ }^{65}$ That left only the retailer with a mixed inventory of goods of small unit value unprovided for-but no financing agency has ever been inclined to advance money on such unsatisfactory security, quite apart from the metaphysical question of whether its lien would be valid. Nevertheless, many states over the past fifteen years have gone the rest of the way and validated the floating charge without limitation under so-called Factor's Lien Acts. ${ }^{60}$ These Acts have not been widely publicized and their presence on the books of a jurisdiction sometimes comes as a surprise even to lenders operating in the inventory field. Today the only effect of the no-lien-on-a-shifting-stock rule is to penalize an occasional mortgagee whose counsel failed to advise him that, while his mortgage would be invalid, the security he desired could be validly obtained under a field warehousing arrangement or under trust receipt or under the Factor's Lien Act. In validating the floating charge Article 9 merely recognizes the fact that it is everywhere available today.

The same kind of remarks may be directed to the proposed repeal of the rule of Benedict v. Ratner. That rule has already been repealed in many states-in the inventory field by the Factor's Lien Acts, in the accounts receivable field by the accounts receivable statutes. ${ }^{67}$ In so far as it is still in force, compliance with it is on a grotesquely formalistic level: the rule, as developed in a later case, is thought to require a daily remittance from assignor to assignee of all proceeds-i.e., payments received - on assigned accounts. The practice today is for the assignee to make an immediate re-remittance of the proceeds back to the assignor, where a revolving credit

${ }^{\circ}$ The critical case, or at any rate the case always cited in this connection, is $\ln$ re James, Inc., $30 \mathrm{~F}$. 2d 555 (2d Cir. 1929).

${ }^{6}$ Supra note 16.

${ }^{\text {er }}$ Both types of statutes typically contain what may be called an anti-Benedict clause. The repeal is sometimes partial, sometimes total. One of the most forthright repealers is N. C. Gen. STATs. Art. 14, $\$ 44-83$ (Cum. Supp. 1949): "Any permission by the assignee to the assignor to exercise dominion and control over a protected assigned account or the proceeds thereof shall not invalidate the assignment as to third persons." 
arrangement is contemplated. ${ }^{68}$ The only effect of this extra paper-work is to increase the cost of the operation. There is a sound core of sense at the basis of the Benedict rule: the accounts receivable lender, who is tying up the debtor's most liquid asset, should be required to keep a close watch on his debtor's operations: as lending practice has developed in this field it has been found necessary for the lender's own protection for him to keep such a watch, irrespective of statutory repeal of the rule. That is, experience in jurisdictions which have already repealed the rule indicates that the substance of the rule is retained as a matter of sound business practice; repeal does however allow the lender to dispense with a number of costly formalities. ${ }^{69}$

The objections raised to the liberalization of default procedures are also serious enough to warrant specific discussion. Presumably there will be agreement that the aim of the law here should be to promote disposition of the collateral at the highest possible price. It is my firmly held belief that the requirements of public sale, specified holding periods, a terminal selling date, and so on not only do not accomplish the end; they make it impossible to dispose of the collateral at a decent price. The rules were designed to prevent fraudulent practices by lenders; the cure, which has proved worse than the disease, has been to forbid the use of normal commercial channels for disposing of goods of the type involved. Nor has this paralyzing restriction even served to deter fraud: it is common knowledge to anyone with experience in the field that bankruptcy and foreclosure sales are frequently dominated by local gangs of thieves who manage, by collusive arrangements, to buy up the goods at a fraction of their value and grow fat by resale at and through the market. Article 9 proposes to encourage the disposition of collateral through regular channels. There is of course no assurance that lenders will in all cases act with rigorous honesty. Therefore the concurrent proposal is to give to the courts much greater powers of review over the fairness of the disposition than they have hitherto had. It is almost impossible to upset a foreclosure sale for "fraud"; Article 9 therefore proposes the standard of "commercial reasonableness"-the scope of which is very deliberately left to the courts. ${ }^{70}$ Nevertheless, in fairness to lenders, procedures are also provided

${ }^{88}$ Note the following provision found in a standard accounts receivable agreement used by a large finance company: "We [i.e., the assignor] shall remit the collections to you [i.e., the assignee] in kind duly endorsed, or will immediately send you our check for the amount thereof, and unless the instruments received by you are dishonored, or unless you shall have re-remitted to us the amount thereof at our request, you shall credit the amount thereof on our collateral notes promptly after receipt by you. Said daily remittances shall cover collections made during the preceding day, or the same day if convenient." (Italics supplied.)

${ }^{\circ}$ Section 9-208, repealing Benedict $\nu$. Ratner, should be read in connection with Section 9-306(2) which, following the Uniform Trusts Receipts Act $\$$ ro, restricts the lender who has not subjected accounts to his control to a priority in insolvency proceedings in the amount of collections received within ro days preceding institution of the proceedings. This provision gives effective protection to the other creditors in place of the formal protection which they have under Benedict.

${ }^{70}$ Note also the language of Section 9-507: "If it is established that the secured lender is not proceeding in accordance with the provisions of this Part [i.e., Part 5, Rights on Default], sale may be ordered or restrained on appropriate terms and conditions." 
by which a lender can protect himself against ex post facto charges of "unreasonable" disposition. ${ }^{\text {11 }}$

Inflexible statutory procedures, unaccompanied by close administrative or judicial supervision, have never done anything to prevent fraud and never will. On the rockiest ledge, in the tiniest cranny, through the most nearly invisible loophole, fraud knows how to flourish luxuriantly. This is disquieting but true. The business of drafting a statute is a humbling and rather terrifying experience, but on one matter at least I have little doubt: the Article 9 default provisions cannot work worse than the present rules. There is reason to believe they will work a great deal better.

Detailed refutation of each count in the indictment would make dull reading. Many of the rules which Article 9 will abolish have a long and distinguished history in the law. In almost every instance there was reason and need for the rule, when it was introduced. Changes in the organization of our economy, which the rules have been powerless to prevent or impede, have made many of them obsolete; in so far as they have surviving force, it is to fetter, block, make more uncertain and more expensive financing operations which have come to be regarded as legitimate and seem in any case to be necessary.

Milestones in the past, these rules are only millstones now.

I would answer in much the same way the argument that simplifying the taking of security will tend to dry up the sources of unsecured credit. The transition from unsecured to secured financing has already largely taken place. If the rules were designed to keep financing on an unsecured basis, they have not done so. Article 9 recognizes an accomplished fact, which may be unhappy but which there is no longer any use in denying. Financing patterns develop as they are needed, without much regard to what the law says is permissible or wicked. I have no doubt that this will continue to be the case. As to the possibly inflationary effects of Article 9, I am not enough of an economist-and I tend to believe perversely that no economist is enough of an economist-to be able infallibly to distinguish truth from error. It seems to me, however, that the effective way to control the extension of credit is by direct government action, when needed, and not by reliance on any set of legal abstractions.

The case of the consumer may serve as a bridge from our discussion of the criticisms from the Left to a briefer discussion of criticisms from the Right. Article 9 is attacked as being at the same time unconcerned with and overprotective of the consumer. How much or how little Article 9 should do for the consumer, or about the special problems arising in the consumer field, has caused more debate than any other single matter that has been considered in course of drafting. The present state is an uneasy compromise between those who wanted detailed regulation of all the plague spots in the field and those who argued that Article 9 should leave consumer problems rigorously alone.

\footnotetext{
${ }^{31}$ Supra note 64.
} 
The initial drafting plan called for a separate Part of the Article dealing with consumer financing. ${ }^{72}$ Early drafts of that Part contained many provisions which no longer appear in current drafts of the Article. For example, rules were stated to regulate the operation of so-called lay-away plans and of add-on clauses in consumer contracts. A rigidly prescribed procedure on default was contemplated. For a time the drafting staff, their advisors, and the two sponsoring organizations seemed in happy agreement that Article 9 should contain a reasonably detailed treatment of consumer financing problems.

The argument was then advanced that the abuses inherent in the consumer field cannot be effectively dealt with by a general codifying statute; that the only workable solution is the establishment of state administrative agencies with licensing and rule-making powers, with funds sufficient to allow continuing supervision of consumer financing and with authority to revoke or suspend licenses for violations. The National Conference of Commissioners on Uniform State Laws took the position that the drafting of a statute setting up such an administrative agency transcended its powers. The proponents of administrative control then argued that the attempt to regulate abuses in consumer financing be eschewed entirely. This argument was grounded on two propositions: First, that legislative developments of the past few years give reason to believe that many states, if left to themselves, will enact effective consumer legislation. ${ }^{73}$ Second, that since the Commissioners' view of their jurisdiction precludes the drafting of effective legislation, the best that the Code can do will be to afford the consumer an illusory degree of protection which will mask abuses without correcting them, but which will, in view of the prestige of the sponsoring organizations, block the passage of more satisfactory legislation.

At a later point a significant new idea was introduced into the debate: that quite without regard to the effectiveness of proposed security legislation, a fundamental mistake was being made in thinking of the consumer security transaction as an appropriate unit for legislation. According to this line of thought, all transactions in which consumer debt is incurred should be regarded as the area to be covered, whether the debt is secured or unsecured. A confused network or patchwork of unrelated statutes already covers various aspects of consumer lending: state small loan acts, federal lending acts, credit union acts, industrial bank acts, pawnbrokers' acts, and so on. What is needed is a general statute to supersede the present unsatisfactory patchwork and to codify the law of consumer debt; ${ }^{74}$ not another statute which covers only part of the field and which is in any case ill-conceived since it focuses on the less important aspect of the transaction rather than on the more important-on the security rather than on the underlying debt.

\footnotetext{
${ }^{72}$ See the May 1949 Draft of the Code, Part 6 (Consumer's Goods Financing) of the Article, which was then numbered 7 .

${ }_{73}$ There is certainly a great deal of legislative activity in this field. A person who should know has told me that Retail Instalment Selling Acts may be presented to as many as twenty state legislatures during 1951. How much "effective" legislation will result is a matter for speculation.

"S See Hubachek, The Drift toward a Consumer Code, x6 U. of CH. L. Rev. 609 (1949); Bogert, The Future of Small Loan Legislation, 12 U. of Crr. L. Rev. I (1944).
} 
These arguments have been in large part successful. The original idea of a comprehensive regulation of the consumer security transaction has been abandoned. There has been nevertheless a strong feeling, among some members of the drafting staff and in the sponsoring organizations, that the field should not be entirely abandoned. There is no disposition to quarrel with the arguments that administrative control of consumer security transactions is more effective than anything the Code can do and that a comprehensive consumer code would be best of all. Still, it is pointed out, to date only thirteen states have passed any kind of Retail Instalment Selling Act; only a few of these provide even on paper for a satisfactory degree of administrative control, ${ }^{75}$ and no one really knows much about how those have worked; furthermore, a case can be made that the acts, as they are passed by state legislatures, are being year by year progressively emasculated. As for the comprehensive consumer code, that is at present only a mirage. Pending Utopia, it is suggested, something is better than nothing. A well-drawn disclosure statute can do no harm, may do some good, and will be a distinct advance in the thirty-five states presently without any legislation in the field of instalment selling.

This is one of those unhappy debates in which a reasonable man may be forced to admit that there is much to be said on both sides. To date the forces of compromise have carried the field. A disclosure statute, which goes well beyond the provisions of the Model Act, has been maintained-albeit with instructions to the drafting staff to make clear, by printing the section within brackets and by an accompanying Note, that the section is an optional one and that states which already have satisfactory legislation should delete it. The debate, however, continues and it may be that the present solution will give way to another before Article 9 is promulgated.

The treatment of waiver of defense clauses and the consumer's negotiable note ${ }^{70}$ deserves a paragraph. I do not believe that these problems, in the consumer field, are as important as the publicity they have received would lead the casual observer to believe. ${ }^{77}$ They are matters which fascinate lawyers but leave businessmen unmoved. So far as the negotiable note is concerned, there are indications in the case law that the finance company assignee will not much longer be allowed to claim as a holder in due course of such notes, ${ }^{78}$ and some state statutes have already gone to the length of prohibiting their use. ${ }^{79}$ In its treatment of the consumer's negotiable note, Article 9 follows a well-blazed trail. The waiver of defenses clause, used as a substitute for the negotiable note, has met a mixed reception at the hands of the

${ }^{75}$ For example, IND. STAT. ANN., \$58-901 through $\$ 58-934$ (Burns I943).

${ }^{70}$ Supra, pp. 38-39.

${ }^{77}$ I ventured this suggestion several years ago (Gilmore and Axelrod, Chattel Security, 57 YaLE L. J. 5I7, at $54 \mathrm{I} \mathrm{n.} 58$ (1948)) and have learned nothing since then to make me change my mind. Even Kripke, supra note 54, at 1216 , in the course of a vehement attack on the Article 9 provisions, concedes: "While the extent of the problem has been exaggerated, it does cxist to a limited extent . . ."

${ }^{78}$ A recent case is Commercial Credit Corporation v. Orange County Machine Works, 32 Cal. $2 \mathrm{~d}$ 847, 214 P. 2d 819 (1950).

${ }^{79}$ As in the Pennsylvania Motor Vehicle Sales Finance Act, 69 P S $\$ 61_{5}$ (g) (Supp. 1949). 
courts. $^{80}$ In some cases it has been held void as an attempt to create a negotiable instrument outside the framework of the Negotiable Instruments Law; in others it has been upheld as a permissible exercise of freedom to contract. Although the clause, as usually drafted would, if given its full scope, cut off all defenses, I know of no case upholding the clause in which the defense present was other than a personal defense, to use negotiable instruments terminology. I think the Article 9 proposal to invalidate the waiver in the consumer field and to allow it the same effect as a negotiable note in commercial financing is sound. The operation of the large sales finance companies will not in fact be impeded; some marginal abuses will be at least discouraged; in the commercial field, where the waiver is appropriate, financing will benefit from having the waiver put on a safe statutory footing.

Financing institutions have much more to gain by the enactment of Article 9 than they can possibly lose. Their gain will be in large part the debtor's gain as well. No one should expect something for nothing, and the lenders are being asked to pay a price. The price is stated in the imposition of duties of care on the part of the lender which cannot be contracted out of; in the incorporation of provisions designed to protect the borrower and his other creditors from the undesirable effects of permitting one lender to achieve a monopoly position by tying up all of a debtor's assets; ${ }^{81}$ in the requirement of public filing for all non-possessory security interests; and in casting on the lender certain business risks, which arise from the chosen debtor's fraudulent activity. Some of the new provisions are introduced as effective substitutes for outworn protective devices. Others make explicit doctrines which have been implicit in the law, and thus in a position to be conveniently overlooked. ${ }^{82}$ The price asked is not unreasonable; the bargain offered allows for a fair profit on the transaction. In dealing with special interest groups over the past few years I have, however, at times found it difficult to escape the impression that what was being demanded was a free statutory subsidy-although I should like also to pay tribute to those who have found it possible to make their invaluable specialized knowledge available to the draftsmen without ever losing sight of the truth that the statute should, above all else, be drawn in the public interest.

The objections from the Right are in most instances technical, and lack the epic sweep of the objections from the Left. The objector typically wants the gravy on his helping spread just a little thicker. It is not unreasonable for a businessman to ask for all he thinks he has a chance of getting. It is entirely proper for a lawyer to oppose strenuously any shift of legal doctrine which may be theoretically adverse to his client; the proposition that the law should reflect actual business practice loses its attractiveness when that means scrapping legal weapons, which, although they may not have been used for a hundred years, are still comfortable to have around.

${ }^{80}$ See Note, Negotiability of Conditional Sales Contracts: The Constcmer and Article III of the Commercial Code, 57 YaLE L. J. I4I4 (1948).

${ }^{81}$ See, for example, Sections 9-308, 9-312.

${ }^{82}$ Such as the statement in Section 9-210 on the lender's duties with respect to collateral in his possession. Cf. Restatement, Secunity $\$$ I7-I9 (194I). 
When there is an ox to be gored, we all prefer it to be our neighbor's ox and not our own.

Even so, there comes a time when negotiations must end and decisions must be made. With the Code scheduled for promulgation in $195 \mathrm{I}$ and presentation to legislatures in 1952 and 1953 , that time is at hand. I do not believe that the sponsoring organizations will consent to dilution of Article 9; further changes will be restricted to technical corrections of minor details. Interested groups must shortly make up their minds whether to oppose or to support or to maintain a passive handsoff attitude.

The choice is not between Article 9 and the good old law. In the first place, there never was any good old law. In the second place, if Article 9 is rejected, the alternative is not the law as it is but an indefinite series of yearly legislative tinkerings, the result of which cannot help being worse than the worst which can be predicted for Article 9.

Article 9 has one important and undeniable virtue: it exists. It is a long, expensive, and tedious task to draft a statute of this magnitude. Putting Article 9 together has almost continuously over a three year period absorbed the time and energies of a drafting staff of four people; has taken large chunks of time of a group of advisors; has demanded many days of consideration and debate on the floors of the American Law Institute and the National Conference of Commissioners, not to mention weeks given to conferences with representatives of industries, financing institutions, bar associations, and so on. If the Article is enacted, the bugs that will of course show up can without undue difficulty be remedied by amendment after a five-year run. If it is rejected, the whole frightful job will eventually have to be done over again by other hands: I am convinced that the idea of Article 9 is too good to die even if the Article itself is rejected. But the position which would necessarily be taken by its opponents would, if their opposition were successful, make it impossible for them to revert to the need for a codification of chattel security law for a good many years.

By its nature Article 9 cannot become a matter of any great public interestalthough there is a certain amount of fun in imagining the Governor of Connecticut or of North Carolina running for re-election on the issues of the after-acquired property clause and the floating charge. It is a technical statute for specialists. Unfortunately all the specialists are on the same team and there is no opposition. Financing operations in this field have become so complex that no one, except the operating men and their counsel, any longer understands them. It is a fair guess that at legislative hearings, apart from the local Commissioners on Uniform Laws, no one will show up except bank and finance company counsel, appearing either in that capacity or as representatives of local, state and national bar associations. To the extent that the passage or defeat of legislation depends on rational grounds, Article 9 will pass or fail depending on the attitude to be taken by the representatives of the financing industry.

May their choice be wise. 